\title{
Os prefácios dos romances iniciais e o método de composição de Machado de Assis
}

\author{
Cilene Margarete Pereira*
}

\begin{abstract}
Resumo: Este artigo discute a importância dos textos introdutórios, denominados advertências, para o entendimento da obra ficcional de Machado de Assis, destacando o prefácio de seu primeiro romance, Ressurreição, de 1872. Nele, o escritor aponta seu método de construção ficcional baseada na caracterização e oposição das personagens a partir de alguns versos motivadores de Shakespeare, retirados da peça Medida por Medida.
\end{abstract}

Palavras-chave: Prefácio. Romance. Composição. Personagem. Oposição.

Há muito já se sabe a importância que os textos introdutórios às obras, comumente denominados prefácios, têm para o entendimento e leitura destas. Os escritores, especialmente os romancistas, desenvolveram ao longo dos tempos técnicas sofisticadas e criativas para dialogar com seus leitores neste curto, mas significativo, espaço textual. Normalmente, os prefácios desempenham a função principal de mediadores entre as ideias e concepções do escritor e seu público, servindo, muitas vezes, como espécie de "guia de leitura", oferecendo instruções sobre a obra ou como dela extrair maior prazer e/ou conhecimento. Essa relação íntima entre autor e leitor é quase sempre explorada pela ótica da adulação e da identificação entre estes dois elementos formadores do processo de significação da obra. Associado a este papel primordial, o prefácio revela outras funções de grande interesse, especialmente ligada aos processos de construção da obra literária, pois serve também como espaço à resposta de críticas e elogios, reflexões de cunho artístico e exercícios de lustração do ego do escritor e, muitas vezes, de porta de entrada para a ficcionalidade.

Ainda que seja na segunda fase de sua vida literária que Machado de Assis conceberá romances e contos de maior complexidade, prefaciados por textos mais ambíguos e cifrados (e em grande parte também ficcionais como ocorre em Memórias

\footnotetext{
"Doutora em Teoria e História Literária (UNICAMP); Professora e Coordenadora do Mestrado em Letras da Universidade Vale do Rio Verde (UNINCOR); Pesquisadora Colaboradora do IFCH/UNICAMP, onde faz a pesquisa de pós-doutorado "Das páginas dos jornais ao livro: versões narrativas dos contos machadianos e Editora da Revista RECORTE. E-mail: prof.cilene.pereira@unincor.edu.br.
} 
póstumas de Brás Cubas, Esaú e Jacó e Memorial de Aires); já em sua fase inicial, ele encena sua veia narrativa para a construção de advertências reflexivas e contundentes, entremeadas por críticas (e autocríticas) e boa dose de espirituosidade. É assim que ele constrói o prefácio introdutório a Ressurreição (1872), seu primeiro romance. Pautando sua advertência ${ }^{1}$ em oposição aos demais e correntes prefácios da época, escritos com expressão de "falsa modéstia", o escritor tende a distanciar-se destes, assumindo um caráter aparentemente sincero em relação às críticas negativas e/ou positivas advindas da apreciação do seu romance.

Para explicitar a distinção do prefácio (e do homem que o escreveu), Machado de Assis se vale de uma longa glosa a respeito da caracterização comum dos textos introdutórios, ressaltando sempre a aparente modéstia dos seus autores.

\begin{abstract}
A crítica desconfia sempre da modéstia dos prólogos, e tem razão. Geralmente são arrebiques de dama elegante, que se vê ou se crê bonita, e quer assim realçar as graças naturais. Eu fujo e benzo-me três vezes quando encaro alguns desses prefácios contritos e singelos, que trazem os olhos no pó da sua humildade e o coração nos píncaros da sua ambição. Quem só lhes vê os olhos, e lhes diz verdade que amargue, arrisca-se a descair no conceito do autor, sem embargo da humildade que ele mesmo confessou, e da justiça que pediu.

Ora pois, eu atrevo-me a dizer à boa e sisuda crítica, que este prólogo não se parece com esses prólogos. (ASSIS, 1997, p. 116).
\end{abstract}

Algo que chama a atenção do leitor imediatamente é o fato de Machado se colocar à disposição do julgamento crítico de maneira aberta, assumindo uma posição respeitosa (sem deixar de ser um pouco impertinente) em relação à "boa e sisuda crítica". Sua descrição dos prólogos comuns realça sua sinceridade ao revelar o quanto ele quer se distanciar dos "arrebiques de dama elegante, que se vê ou se crê bonita". Aliado a isso está a constatação da necessidade do envolvimento da crítica, de maneira benévola, porém "franca e justa" para o aprendizado do escritor.

Aplausos, quando os não fundamenta o mérito, afagam certamente o espírito e dão algum verniz de celebridade; mas quem tem vontade de aprender e quer fazer alguma coisa, prefere a lição que melhora ao ruído que lisonjeia. (ASSIS, 1997, p. 116). ${ }^{2}$

Certo é dizer que Machado de Assis faz-se aqui com ares de aprendiz de romancista (de aprendiz humilde, mas ambicioso), pois não só a vontade de aprender o impulsiona como o desejo de "fazer alguma coisa" no campo literário. A afirmação do escritor sugere a visão do romancista iniciante sedento por realizar-se no gênero

\footnotetext{
${ }^{1}$ Machado denomina sempre seus prefácios como advertências.

2 Questões relativas à forma "correta" de julgamento de uma obra estão expostas no artigo "O ideal crítico" (1865), em que Machado postula com bastante lucidez sobre os quesitos necessários à boa crítica. Entre eles se destaca o papel da crítica na fecundação da literatura brasileira: "Estabelecei a crítica fecunda, e não a estéril, que nos aborrece e nos mata, que não reflete nem discute, que abate por capricho ou levanta por vaidade; estabelecei a crítica pensadora, sincera, perseverante, elevada, - será esse o meio de reerguer os ânimos, promover os estímulos, guiar os estreantes, corrigir os talentos feitos; condenai o ódio, a camaradagem e a indiferença, - essas três chagas da crítica de hoje, - ponde em lugar deles, a sinceridade, a solicitude e a justiça, - é só assim que teremos uma grande literatura." (ASSIS, 1997, p. 798).
} 
romance, a despeito de já ser jornalista, poeta e contista de algum renome. Essa ideia persiste em seu prefácio, acrescida de outros elementos vitais ao desejo de amadurecimento do autor: a reflexão e o estudo. Não falta a esse Machado ainda juvenil, iniciando-se na arte do romance, a consciência da dificuldade do labor artístico, especialmente quando este se associa de modo intrínseco ao estudo e à reflexão (própria do amadurecimento humano). Persistindo no exercício de sua sincera humildade, Machado pontua seu prefácio na caracterização e distinção entre os "gênios, a quem a natureza deu o poder quase inconsciente das supremas audácias", e a "lei das aptidões médias, a regra geral das inteligências mínimas", (ASSIS, 1997, p. 116) lugar onde se coloca ambicioso por alcançar (e merecer) posição mais elevada. Assim, ao mesmo tempo em que Machado pontua seu prefácio pela distância que guarda dos prólogos comuns, ele esbarra no limite que os diferencia, praticando, de maneira mais disfarçada e consciente, a tópica da modéstia. Isso pode ser visto não como uma maneira enganosa de se insinuar ao leitor, mas tão somente como modo usual de criar uma espécie de identificação com seu público, apelando para uma leitura justa e condizente com seus propósitos romanescos.

O prefácio de Ressurreição tem um caráter bastante explicativo (algo que será abolido pelo autor na chamada fase madura), pois Machado faz questão de evidenciar o modo de construção de seu primeiro romance, chamando-o mesmo de "ensaio". Ensaio de um tipo de romance que deseja realizar e tentativa de se expressar em um gênero novo para ele. Um dos motivos que o levaram a se arriscar neste "gênero novo" é a benevolência com que leitores e crítica receberam Contos Fluminenses (1870), um volume com sete textos ficcionais de longa proporção que são caracterizados pelo autor como "contos e novelas".

Não é sem razão que grande parte do pequeno prefácio de Ressurreição se estrutura em torno da apresentação do romance, observando seu processo de construção e a ideia que o originou: versos retirados da peça Medida por Medida, de Shakespeare.

\footnotetext{
Minha ideia ao escrever este livro foi por em ação aquele pensamento de Shakespeare:

Our doubts are traitors,

and make us lose the good of might win,

by fearing to attempt. ${ }^{3}$

Não quis fazer romance de costumes; tentei o esboço de uma situação e contraste de dois caracteres; com esses simples elementos busquei o interesse do livro. (ASSIS, 1997, p. 116).
}

Mesmo que Machado de Assis não chegue a teorizar de maneira satisfatória sobre seu modo de construção romanesco - apesar de ter deixado vários escritos críticos, Machado nunca formulou explicações teóricas sobre sua obra ${ }^{4}$-, fica evidente

3 O trecho corresponde à fala de Lúcio que interpela Isabel por duvidar de sua força em favor do
irmão condenado à morte. A tradução próxima seria: "Nossas dúvidas são traidoras, /E fazem-
nos perder o bem que poderíamos obter, /Por receio de o buscar."
4 Ainda sim é possível especular sobre os anseios e a maneira como Machado entendia a
literatura, especialmente o romance, à medida que nos valemos de seus escritos críticos. Os 
que, aqui, ele dá alguns indícios de como pensava o gênero. Objetivando criar um romance que pusesse em ação o pensamento de Shakespeare por meio da oposição de duas personagens, a partir de uma dada situação (no caso, o compromisso amoroso), Machado parecia estar afirmando a importância da concepção da personagem para o direcionamento do enredo/conflito. Ou seja, ao construir seu casal protagonista nas figuras do indeciso e frio Félix (personagem que encena o pensamento shakesperiano) e da resoluta e sentimental Lívia, Machado mostrava a força de ação da personagem na construção romanesca. Em muitas de suas histórias o interesse recai essencialmente sobre os caracteres de suas figuras ficcionais e no modo como elas se constroem ao longo de suas próprias trajetórias. Não por acaso, a estrutura de Ressurreição (e de outros romances) se assemelha, guardadas as devidas proporções, à composição da "narrativa de formação", já que explora o processo de amadurecimento emocional/intelectual das personagens, que é revelado a partir da interação com outros códigos de conduta e experiências morais. ${ }^{5}$

Essa ênfase na personagem literária está também marcada nos textos críticos de Machado, dos quais o relativo ao romance de Eça de Queiroz, O Primo Basílio, ocupa posição de destaque. Na avaliação que o escritor faz do texto, ele centra suas negativas em torno da concepção da principal personagem feminina, mostrando-a ausente de qualquer "força moral". Para o crítico Machado, "Luísa é um caráter negativo, e no meio da ação ideada pelo autor, é antes um títere do que uma pessoa moral. [...] não Ihe peçam paixões nem remorsos; menos ainda consciência." (ASSIS, 1997, p. 905). ${ }^{6}$ Machado destaca a oposição existente entre "títere" e "pessoa moral", afirmando a ineficácia de uma narrativa que escolhe modelar sua personagem a partir da primeira concepção, já que sugere a desvinculação entre ela e o leitor. Essa oposição marca sua crença na personagem individualizada por meio de valores e sentimentos próprios, que ajudam a definir sua trajetória como indivíduo atuante na trama.

Opondo Ressurreição ao "romance de costumes", e eximindo-se talvez de uma injusta crítica de seus leitores (seria isso uma espécie de justificativa diante o gosto de seu público?), Machado concebe algo que, desde já, será vital para os processos de construção de sua obra ficcional, o "romance de (análise) personagens" e da exploração psicológica destes. Em seu mais importante texto crítico, "Instinto de Nacionalidade" (1873), escrito um ano depois do lançamento de Ressurreição, o escritor observa a dificuldade, entre nós, da construção do "romance puramente de análise", especialmente em detrimento ao frequente "romance de costumes":

ensaios fundamentais, nesse sentido, são "Instinto de Nacionalidade", "O ideal crítico", "Presente, passado e futuro da Literatura Brasileira"; e as críticas relativas às obras de Macedo, Alencar e Eça de Queiroz.

5 Karin Volobuef explica que o "romance de formação" foi uma das formas mais correntes do romance romântico, já que em seu cerne "está uma das preocupações-chave do romantismo alemão: a formação do indivíduo e o pleno desenvolvimento de suas faculdades", sendo, pois, o motivo da viagem fundamental, na qualidade de promover "o encontro com pessoas diferentes, que lidam com a vida e encaram a arte de perspectivas diversas." (VOLOBUEF, 1999, p. 4347). Por esta simples e rápida conceituação, já fica claro que a narrativa machadiana refere-se, de certo modo, a essa estrutura, sem ceder integralmente a ela.

${ }^{6} \mathrm{O}$ texto crítico de Machado é de 1878. 
Aqui o romance, como tive ocasião de dizer busca sempre a cor local. A substância, não menos que os acessórios, reproduzem geralmente a vida brasileira em seus diferentes aspectos e situações.

[...]

Não faltam a alguns de nossos romancistas qualidades de observação e de análise, e um estrangeiro não familiar com os nossos costumes achará muita página instrutiva. Do romance puramente de análise, raríssimo exemplar temos, ou porque a nossa índole não nos chama para aí, ou porque seja esta cesta de obras ainda incompatível com a nossa adolescência literária.

o romance brasileiro recomenda-se especialmente pelos toques do sentimento, quadros da natureza e de costumes, e certa viveza de estilo mui adequada ao espirito do nosso povo.

[...]

Pelo que respeita à análise de paixões e caracteres são muito menos comuns os exemplos que podem satisfazer à crítica; alguns há, porém, de merecimento incontestável. Esta é, na verdade, uma das partes mais difíceis do romance, e ao mesmo tempo das mais superiores. Naturalmente exige da parte do escritor dotes não vulgares de observação, que, ainda em literaturas mais adiantadas, não andam a rodo nem são a partilha do maior número. (ASSIS, 1997, p. 804-805)

O trecho destinado ao exame do romance se constrói pela oposição, como se vê, entre o tipo mais explorado por nossos romancistas ("romance de costumes") e o modelo menos utilizado e mais difícil do gênero, segundo Machado de Assis, aquele "puramente de análise das paixões e dos caracteres" - forma evidenciada no seu primeiro "ensaio" romanesco, conforme nos informa seu prefácio. É singular que o escritor se preocupe com um tipo de romance que tentara construir um ano antes, mostrando que a questão já estava na ordem de seus pensamentos, mas também servindo como justificativa das falhas obtidas nesse processo de construção do texto, já que o gênero é difícil e pouco experimentado pelos escritores do momento. "Instinto de Nacionalidade" prega ainda que o escritor pode e deve falar das coisas locais, porém dando-Ihes um tom mais universal "que o torne homem de seu tempo e do seu país, ainda que trate de assuntos remotos no tempo e no espaço", (ASSIS, 1997, p. 804) conferindo outra saída para a questão da nacionalidade literária brasileira do que a sugerida pela exploração da "cor local".7 Pondo em ação, em Ressurreição, o pensamento de Shakespeare, Machado dá universalidade às suas personagens, ainda que estejam localizadas no espaço social/temporal da capital do II Império Brasileiro. Nessa perspectiva, vemos que "Instinto de Nacionalidade", escrito para dar "notícias da atual literatura brasileira", serve também como uma espécie de posfácio à Ressurreição, pois mesmo sem se deter no romance, Machado de Assis o explica, destacando ainda suas diretrizes básicas para a formação/consolidação da literatura (e do romance) no Brasil.

É possível perceber que Ressurreição, a despeito de ser o ensaio de um "romance puramente de análise", é construído principalmente a partir da concepção das personagens. Em um primeiro momento essa afirmação pode soar estranha, pois sabemos que em sua fase madura Machado ascenderá como um dos maiores escritores de nossa língua justamente (mas não só por isso) por ser capaz de construir e modificar a posição do narrador na prosa literária brasileira. Ao conceber narradores

7 Nessa linha de ideia ver Abel Barros Baptista e seu estudo sobre o ensaio "Instinto de Nacionalidade" em $A$ formação do Nome. 
dotados de altíssima complexidade, ele estaria relativizando a verdade de seus relatos, entendendo-os como atores sociais comprometidos com os valores e ideologias da classe a qual pertencem. Mas independente de serem Bento Santiago, Brás Cubas ou Aires exímios narradores, são também personagens, e é devido a suas experiências como personagens que se fazem narradores - e narradores dessa qualidade: os narradores nascem da experiência social e existencial da personagem. Nesse sentido, afirmar a importância da concepção do narrador no romance machadiano, especialmente o de primeira pessoa, é apontar também a força fundamental que esses seres têm como personagens. ${ }^{8}$

Em A estrutura do romance, Edwin Muir (1975) analisa a organização textual dos dois principais tipos de romances, o de personagens e de ação, observando que 0 primeiro apresenta, por meio de situações típicas, personagens menos elaboradas, que são apresentadas da mesma forma tanto no início quanto ao final da narrativa ("personagens planas" na expressão de Forster); enquanto que o segundo se estrutura a partir de uma série de situações inusitadas que tem por finalidade empreender ação ao romance, objetivando a construção de um enredo preciso (e por vezes rocambolesco), não se importando com a configuração das personagens - é a ação o que realmente preocupa o romancista. Segundo o crítico, essas duas estruturas (do "romance de ação" e do "romance de personagens") darão origem ao "romance dramático", um tipo mais complexo de texto ficcional, em que desaparece o hiato entre personagem e ação. A fim de investigar melhor as personagens (e fazê-las agir) há uma limitação do círculo social. As personagens têm consequências, influenciam em acontecimentos, criam dificuldades e, em circunstâncias diferentes, as resolvem.

Observando essa explicação teórica a respeito da estrutura dos romances, é possível discutir a associação de Ressurreição ao "romance de personagens" e estendê-la às concepções dos romances "dramático" e "psicológico", pontuando a importância dessas duas formas na obra de Machado de Assis. É claro que a estrutura vislumbrada no "romance dramático" por Muir diz muito a respeito da configuração que Machado dá a Ressurreição, no qual as personagens evoluem timidamente, mas não são plenamente estáticas, pois sugerem, por meio de suas ações, reviravoltas no enredo e contradições em seus caracteres. Algumas delas como Félix, por exemplo, são dotadas de aspectos tão opostos (intensificando o conflito íntimo vivido pela personagem masculina) que se caracterizam exatamente pela fluidez, não sendo possível apreendê-la de todo - pelo menos não da forma que visualizamos as personagens estáticas.

Se por um lado, a concepção de Ressurreição a partir da oposição entre personagens esbarra muito na estrutura do "romance de personagens", é preciso não

\footnotetext{
${ }^{8}$ Além da personagem, o narrador será um ponto importante na composição de Ressurreição - e desses primeiros textos -, já que ele é responsável, em parte, pela apresentação das figuras machadianas. As cenas descritivas, centradas especialmente na observação das personagens, captam, assim como o discurso narrativo que as emoldura, a essência do próprio narrador, que se vale, muitas vezes, de comentários irônicos e desconcertantes em relação aos fatos narrados. As descrições presentes em Ressurreição se adéquam muitos mais à funcionalidade da história do que às exigências do romance romântico, pois que estabelecem meios de levar o leitor a apreender os aspectos mais relevantes da escrita machadiana quanto à caracterização de suas personagens e de seu narrador.
} 
se esquecer de que se refere ainda mais aos moldes do "romance psicológico", pois evidenciar os seres ficcionais é uma forma de Machado de Assis explorar sua psique. De nada adiantaria ao escritor construir um romance a partir de suas personagens sem dar vazão ao movimento interno existente nelas - Machado estaria criando nada mais que "fantoches" ou "títeres" - e essa não é a intenção do autor. Por outro lado, essa concepção inaugural no romance machadiano por meio da construção de personagens abre também possibilidades de entender Ressurreição como participante da estrutura do "romance dramático" dado à equação "personagens + situação" proposta por Muir. De qualquer forma, ainda que não consigamos apreender a estrutura exata do primeiro romance de Machado, visto sua associação a diferentes tipos - pelo menos em termos teóricos claros -, é certo afirmar que sua preocupação está intimamente ligada à construção da personagem e sua exploração psicológica, que sugere sempre a complexidade do ser humano e suas implicações sociais.

Essa importância na concepção das personagens se apresentará também de maneira marcante em seus contos, delineando retratos e perfis bem traçados e complexos, especialmente de mulheres e de seres dotados de estranheza. José Guilherme Merquior observa que, dentre os contos maduros de Machado de Assis, cerca de pelo menos trinta "podem ser rigorosamente classificados de estudos de caráter.". (MERQUIOR, 1977, p. 174). A propósito da construção do conto em Machado de Assis, José Aderaldo Castello destaca este mesmo aspecto:

A arquitetura do conto machadiano, primeiramente, é apoiada no esquema de uma situação adequada à demonstração de caracteres esboçados. Fatos ou acontecimentos são assim configurados muito mais na dependência da análise do que em função de um esquema narrativo. (CASTELLO, 1969 p. 76).

A análise é acentuada por meio de confrontos e contrastes que ora aproximam personagens, ora distanciam as ações e revelam do que são capazes moralmente. ${ }^{9}$ Essa ênfase no caráter, que foi grande marca dos primeiros textos e ideia central na construção de Ressurreição, teria sido uma maneira encontrada por Machado de Assis de se distanciar do modelo maniqueísta do Romantismo, especialmente dotando suas personagens de aspectos contraditórios e irregulares. É preciso observar que ao conceber personagens que se confrontam, Machado não as está apenas dotando de elementos positivos ou negativos, mas faz com que as situações se desenvolvam de modo a colocá-las em posições conflitantes. Isto é, suas personagens não são fixadas a partir de elementos únicos e estáticos (bondade, virtude ou maldade e vício, por exemplo), mas ao se confrontarem com outras deixam expostas novas características que se opõem, inscrevendo boa parte de seus seres de papel no território da ambiguidade ou em seus limites próximos. Esse aspecto da prosa ficcional machadiana, ainda em sua fase inicial, o levará incondicionalmente a desenvolver personagens (e narradores) mais complexos, repletos de contradições e capazes de soluções narrativas bem menos evidentes. Se considerarmos apenas os romances

9 "Na verdade, o que ele procura, essencialmente, é acentuar a análise, por meio de aproximações, confrontos, contrastes, encontros harmoniosos, situações hipotéticas, e dar ênfase à conjuntura moral". (CASTELLO, 1969, p. 76). 
machadianos podemos identificar que a base de construção destes é sempre "mostrar o drama resultante da inter-relação de naturezas contrastantes", conforme observou Helen Caldwell a respeito de Dom Casmurro. (CALDWELL, 2002, p. 31). ${ }^{10}$

Nesse sentido é que podemos eleger o prefácio de Ressurreição como uma espécie de paradigma de construção dos textos ficcionais de Machado (não só dos romances), já que o próprio autor destaca um aspecto é que marcante em suas intenções ficcionais. Em seu segundo romance, A mão e a luva (1874), essa mesma estrutura volta a aparecer enfatizada também pelo escritor no prefácio da obra.

\author{
Advertência de 1874
}

Esta novela, sujeita às urgências da publicação diária, saiu das mãos do autor capítulo a capítulo, sendo natural que a narração e o estilo padecessem com esse método de composição, um pouco fora dos hábitos do autor. Se a escrevera em outras condições, dera-lhe desenvolvimento maior, e algum colorido mais aos caracteres, que aí ficam esboçados. Convém dizer que o desenho de tais caracteres, - o de Guiomar, sobretudo, - foi o meu objeto principal, se não exclusivo, servindo-me a ação apenas de tela em que lancei os contornos dos perfis. Incompletos, embora, terão eles saído naturais e verdadeiros?

Mas talvez estou eu a dar proporções muito graves a uma cousa de tão pequeno tomo. O que aí vai são umas poucas páginas que o leitor esgotará de um trago, se elas Ihe aguçarem a curiosidade, ou se Ihe sobrar alguma hora que absolutamente não possa empregar em outra coisa, - mais bela ou mais útil.

Novembro de 1874 .

M. De A.

(ASSIS, 1997, p. 198).

Este prefácio revela aspectos que enfatizam o método de construção do texto machadiano - pelo menos até o presente ano de 1874 - e servem, ao mesmo tempo, de complemento à advertência de Ressurreição. Algo que se destaca de imediato é distinção quanto à maneira de composição e veiculação dos dois romances: enquanto A mão e a luva sai capítulo por capítulo, em forma de romance-folhetim no Globo; Ressurreição, ao contrário de alguns romances da época e de alguns escritos posteriormente por Machado, não é publicado em fatias, mas impresso como romance pronto e acabado; sendo, pois, de confecção distinta da experiência anterior do autor em Contos Fluminenses (1870), todas as narrativas, com exceção de "Miss Dollar", advindas das páginas do Jornal das Famílias (abril de 1865 a janeiro de 1869). Se o processo de composição da obra diz respeito ao escritor, refere-se também à figura anônima do leitor, modificando sua apreensão do conteúdo e da forma do escrito:

10 Este mesmo princípio está no cerne da construção das personagens principais em Helena (Helena e Estácio/Estácio e o Conselheiro Vale/Eugênia e Helena/Camargo e Estácio) e em Iaiá Garcia (Estela e Jorge/Jorge e Valéria/Estela e Antunes/Iaiá e Estela/Luís Garcia e Antunes). Todas essas oposições se afirmam continuadamente, assemelhando as personagens em alguns aspectos e se distanciando em outros. Dessa forma torna-se difícil conferir alguma polaridade (positivo ou negativo) às personagens. Mas é na segunda fase machadiana que este confronto entre naturezas contrastantes, especialmente encenado no campo amoroso, será mais marcante e complexo. As leituras de Helen Caldwell (2002), John Gledson (1991) e Roberto Schwarz (1997) são algumas que destacam a oposição entre os caracteres de Bentinho e Capitu. Essa mesma estrutura se converterá em esquema básico de construção de personagens em Esaú e Jacó, em que a oposição constante dos gêmeos Pedro e Paulo é levada às últimas consequências pelo autor como forma de ressaltar a similaridade entre ambos. 
Uma coisa é ler [ou escrever, poderíamos inserir] um romance aos pedaços, com intervalos determinados pelo órgão de divulgação e a inserção diária de experiências alheias ao mundo ficcional; oportunidade muito diferente oferece o livro cuidadosamente impresso, facultada a possibilidade de avançar, recuar, anotar e refletir. (SCHÜLER. 1989, p. 58).

Pensar o romance como modelo acabado e assim estruturado por Machado de Assis é principalmente observar a ausência de diálogo com seu leitor - o que possivelmente ocorria com os textos escritos para os jornais e revistas da época. ${ }^{11}$ Esse método, certamente, interfere no trabalho do escritor (assim como no de decifração e entendimento do leitor) que teria espaço e tempo suficientes para estruturar adequadamente seu texto, dando melhor acabamento e coerência interna. Essa distinção salientada pelo próprio escritor pode ser vista como maneira de se desculpar pelo resultado final do romance, mas mostra também que o método aplicado a Ressurreição é bem mais favorável ao romancista iniciante. A "urgência da publicação diária" atrapalharia "o método de composição" do romance, gênero ainda novo para ele.

É preciso reconhecer que Machado sabe avaliar bem os defeitos de sua obra e acerta ao direcionar parte da culpa, quanto à composição do romance, ao método folhetinesco. Se há defeitos de composição em A mão e a luva, especialmente nos caracteres apressados das personagens, conforme avalia o autor, eles são frutos de seu próprio processo de composição. Assim, o escritor parece estar se isentando dos problemas advindos da obra; entretanto, essa explicação é absolutamente importante para compreendermos sua dificuldade em lidar com este "gênero novo", tão indomável (e aglutinador) como o romance.

Ainda que uma avaliação crítica de A mão e a luva não possa ser feita sem ressaltarmos seus problemas de composição, é justo afirmar que este romance, baseado também no princípio do confronto entre caracteres, esboça com clareza e naturalidade uma situação semelhante à Ressurreição. Guiomar é a personagem em relevância que se oporá a seus pretendentes, cada qual composto de elementos positivos e negativos, mas todos contrastantes com o caráter geral e os desejos da moça. Estevão é governado apenas pelo sentimento e tem sonhos de amor completamente idealizados - é uma personagem absurdamente romântica e, portanto, inadequada. ${ }^{12}$ Jorge, sobrinho da Baronesa, age apenas guiado pela razão, observando as vantagens econômicas e sociais de um casamento com a afilhada (e "filha postiça")

${ }^{11}$ A experiência ocorrida com o conto "Confissões de uma viúva moça" pode revelar, em parte, a participação do leitor nos escritos publicados em formato folhetim. Apesar da suspeita da crítica de que o leitor "caturra" que enxovalha o conto seja o próprio Machado numa atitude publicitária, é interessante pensar até que ponto poderia ter havido uma mudança de tom e de composição no final moralizador dado ao texto.

12 O que não significa que Machado estivesse em acordo com a tópica romântica. Um exemplo bastante claro do questionamento machadiano dos modelos românticos ocorre em $A$ mão e a luva, em que a construção idealista e fatalista de Estevão contribuía para uma espécie de conscientização do leitor da debilidade emocional/narrativa da personagem. A cena de abertura do romance não deixava dúvida em relação à crítica: leitor do insucesso amoroso de Werther e da poesia de Byron, Estevão concebe a morte como saída única para o fim do drama amoroso existente apenas em suas ilusões. As palavras do narrador, no início do romance, marcavam bem o tom de ironia e descaso dado à personagem inadequada às páginas de um romance que versava sobre as ambições (sociais e políticas) de um jovem casal. 
da tia. Será o equilíbrio entre o sentimento (afinidades de eleição) e a razão (desejos de ambição) que governará a escolha de Guiomar para Luís Alves, seu homem e par ideal. Talvez, essa seja a solução encontrada por Machado para enriquecer suas personagens, especialmente as femininas. Se em Ressurreição a personagem central era masculina e dotada de um descompasso grande entre estes dois polos opositores (razão e sentimento); agora o romance se constrói em torno da personagem mulher, esboçando uma constante na obra machadiana, já marcada em seus primeiros textos: a importância crescente das personagens femininas, especialmente daquelas dotadas do senso prático de Guiomar.

Os prefácios das outras obras escritas por Machado de Assis na década de 1870 servem como uma espécie de amostragem dos conteúdos e formas exploradas em seus textos introdutórios. Porém, não há nenhum texto tão esclarecedor em relação aos aspectos de construção como o de Ressurreição. No prefácio de Helena (editado pela primeira vez em 1876, em formato de romance-folhetim no Globo), o autor faz uma autocrítica e ao mesmo tempo se justifica, apelando para o amadurecimento do artista e o envelhecimento da obra e, claro, para a complacência de seu leitor.

Esta nova edição de Helena sai com várias emendas de linguagem e outras, que não alteram a feição do livro. Ele é o mesmo da data em que o compus e imprimi, diverso do que o tempo me fez depois, correspondendo assim ao capítulo da história do meu espírito naquele ano de 1876.

Não me culpeis pelo que Ihe achardes romanesco. Dos que então fiz, este me era particularmente prezado. Agora mesmo, que há tanto me fui a outras e diferente páginas, ouço um eco remoto ao reler estas, eco de mocidade e fé ingênua. É claro que, em nenhum caso, Ihes tiraria a feição passada; cada obra pertence a seu tempo.

M. DE A.

(ASSIS, 1997, p. 272).

Fica sugerido que Machado entendia (e concordava) com a divisão que a crítica fez vigorar em relação à sua prosa ficcional, relacionando Helena à sua fase "romântica", dado o caráter excessivamente romanesco do livro. É importante notar que o escritor, apesar de reconhecer os problemas de sua obra - mas não evidenciálos -, guarda especial predileção por ela e em nenhum momento a nega. O que Machado faz para suavizar a crítica é reportar o livro à primeira fase de sua carreira literária, dando-Ihe importância expressiva para o seu amadurecimento literário. Algo semelhante ocorrerá em relação à Ressurreição, que editado novamente no ano 1905, traz nova advertência:

Esse foi o meu primeiro romance, escrito aí se vão muitos anos. dado em nova edição, não the altero a composição nem o estilo, apenas troco dois ou três vocábulos, e faço tais ou quais correções de ortografia. Como outros que vierem depois, e alguns contos e novelas de então, pertence à primeira fase de minha vida literária.

M. de A.

1905.

(ASSIS, 1997, p. 116). 
Aqui, Machado evidencia a crença de que os romances de sua primeira fase foram importantes para o seu crescimento como escritor, justificando sua obra e, implicitamente, exigindo de seu público certa benevolência. O que chama a atenção na leitura desses prefácios é o caráter humilde do autor e o modo sutil como justifica os pequenos problemas de sua obra, apresentando Ressurreição como um "ensaio" de romance psicológico; A mão e a luva semelhante aos métodos empregados na construção das personagens de seu primeiro romance; Helena e a reedição de Ressurreição como representantes dignos e legítimos de sua primeira fase literária.

O prefácio que introduz sua segunda coletânea de contos, Histórias da meia noite (1873), guarda duas importantes informações; uma relacionada à própria composição do volume, outra, à maneira de Machado lidar com sua crítica e público.

\section{Advertência}

Vão aqui reunidas algumas narrativas, escritas ao correr da pena, sem outra pretensão que não seja a de ocupar alguma sobra do precioso tempo do leitor. Não digo com isto que o gênero seja menos digno de atenção dele, nem que deixe de exigir predicados de observação e de estilo. O que digo é que estas páginas, reunidas por um editor benévolo, são as mais desambiciosas do mundo.

Aproveito a ocasião que se me oferece para agradecer à crítica e ao público a generosidade com que receberam o meu primeiro romance, há tempos dado à luz. Trabalhos de gênero diverso me impediram até agora de concluir outro, que aparecerá a seu tempo.

10 de novembro de 1873 .

M. A.

(ASSIS, 1997, p. 160).

Novamente, vemos repetidas as expressões de humildade ("páginas desambiciosas", "editor benévolo", "agradecer à crítica e ao público") e de atenção respeitosa aos seus leitores, ao mesmo tempo em que propagandeia seu próximo romance. A tentativa contraditória de explicar e anunciar o volume de contos mostra um escritor tomado de cuidados ao se dirigir ao público, pontuando sua obra por um misto de entretenimento e seriedade. Machado toma o devido cuidado para não afastar do âmbito de seus leitores "gente frívola" (devota sincera da leitura como distração) e "gente grave" (expressão da leitura como reflexão) como classificaria anos depois o defunto-autor Brás Cubas. Alguns pressupostos estão sempre presentes nos prefácios iniciais de Machado: a insistente apologia da humildade sincera; agradecimentos ao público e à crítica e a tentativa (às vezes frustrada) de explicar a composição do volume, seja ele representado por vários textos ou por um único - esse aspecto se tornará índice de ambiguidade e ironia nos prefácios dos seus demais volumes de contos.

O prefácio de Ressurreição, paradigmático nesse sentido, é construído tendo em vista essas premissas básicas, além de comportar outros elementos de suma importância: mostrar o entendimento que Machado fazia da arte literária e de sua ideia de aperfeiçoamento estético por meio do estudo reflexivo; e apresentar de maneira explicativa os procedimentos de construção de seu primeiro romance procedimentos que dizem respeito às estruturas dos "romances de personagem e dramático" e que servirão à concretização do "romance psicológico" na ficção brasileira. 
Do mesmo modo que os contos iniciais, Ressurreição é o romance menos contemplado pela crítica machadiana, talvez porque os estudos de Lúcia Miguel-Pereira (1949) e de Roberto Schwarz (1977) tenham direcionado o interesse da crítica para a "trilogia do paternalismo" ou "ciclo da ambição", que compreende os romances A mão e a luva (1874), Helena (1876) e Iaiá Garcia (1878). Nesses livros, a figura paterna (e patriarcal) era propositadamente retirada de cena pelo autor para fazer "falar" a esfera da subordinação, conforme identificou Schwarz. ${ }^{13}$ Ressurreição, ao contrário dos outros romances da fase inicial, não explora os desajustes vindos desse modo de organização social brasileiro; quando muito, esboça contornos ainda tímidos da figura parasitária machadiana, dependente, no romance, dos assomos da irmã rica.

Os comentários críticos a respeito de Ressurreição esbarram em generalizações (e cobranças) de ordem moral e referentes à necessidade da cor local - importantes para a primeira geração de críticos do romance ${ }^{14}$ - e em aspectos modernos, tais como a divergência da prática do "romance de costumes", tão comum ao Romantismo Brasileiro, ${ }^{15}$ e sua quase nulidade de enredo, contrária ao "romance de ação", já que Ressurreição se constrói a partir das "vacilações" do protagonista Félix. Entretanto, não faltou quem avaliasse de maneira bastante negativa essa primeira experiência machadiana no gênero, ressaltando a falta de importância do romance para a trajetória do escritor. Os comentários de Lúcia Miguel-Pereira resumem bem a depreciação do livro mediante sua associação ao romantismo:

Em prosa, não fez, de início, o que fizera em poesia; não rejeitou deliberadamente as escolas literárias. Ao contrário, procurou enquadrar-se dentro do romantismo. E com isso conseguiu fazer três livros quase inteiramente maus. [Contos Fluminenses, Ressurreição e Histórias da Meia Noite]. [...] Os dois livros de contos pouco valem e talvez sempre valham mais do que o romance. (MIGUEL-PEREIRA, 1949, p, 101-102). ${ }^{16}$

13 A respeito do romance Helena, essa "fala" ganha a designação de "diálogo político dos dependentes" na análise criteriosa que Sidney Chalhoub faz do romance. CHALHOUB, 1998, p. 95-122.

14 Para análise de alguns comentários críticos quando da publicação do livro, consultar GUIMARÃES, 2004, p. 296-319.

15 "Ressurreição, embora fraco, tecido de incidentes tirados ao ambiente do Romantismo Europeu, é uma curiosa tentativa de romance psicológico. Deslocando o interesse do acontecimento objetivo para o estudo dos caracteres, essa novela aparecia em uma linha diferente e conserva para nós um indiscutível ar de modernidade." (BARRETO FILHO, 1969, p. 140). "... o repúdio ao "romance de costumes" esconde, com a sutileza que será marca registrada do autor, a desestima pela narração romântica tradicional; e a opção pelo "esboço de uma simples situação e contraste de dous caracteres", além de sublinhar a recusa do romance de intriga, que ainda seduzia as leitoras do tempo, aponta, na ênfase sobre os caracteres, a via do psicologismo, trilha autônoma e fecunda de sua obra." (MOISÉS, 1983, p. 92). "Ressurreição apresenta mesmo uma estrutura arrojada para a literatura da época. Semelhante arrojo consiste na sondagem íntima de um casal de noivos, sem o suporte factual de uma ação externa cativante." (TEIXEIRA, 1988, p. 15).

${ }^{16}$ Antonio Dimas discorda do parecer negativo de Lúcia Miguel-Pereira, reforçando a importância do livro: "Dizer que Ressurreição é romance menor de Machado é não perceber a vigorosa vocação do romancista para o desenho de personagens ambíguas e escorregadias, que tudo ignoram sobre si mesmas e não sabem nem mesmo do que são capazes e incapazes." (DIMAS, 1983, p. 7). 
A despeito dessas questões relativas ao gênero romance na obra machadiana e a seu julgamento crítico, podemos evidenciar, certamente, que uma preocupação marcante do autor refere-se à construção das personagens. Não só os prefácios de Ressurreição e A mão e a luva postulam isso, mas a própria crítica tem afirmado a questão. Já em seus textos iniciais publicados no Jornal das Famílias, Machado, ainda sem modelos próprios definidos, o escritor começa a esboçar pequenos estudos de caráter. É claro que grande parte dessas criações ficcionais guarda aspectos demasiadamente estereotipados dos modelos excessivamente românticos, mas nem por isso deixam de antever elementos e circunstâncias de interesse do autor. É dessa forma que pode ser lida e examinada grande parte da obra ficcional produzida por Machado nos anos de 1870.

Contos Fluminenses parece servir, de certo modo, de exercício literário aos primeiros romances do escritor. Não só algumas situações narrativas se repetem, como as personagens sugerem sempre algo similar ou contrário de outras, denotando um esboço a ser estudado e devidamente elaborado pelo autor. 0 método de composição explicado no prefácio introdutório de Ressurreição a respeito de seu primeiro romance é também aplicado à construção dos seus contos iniciais. É por isso que uma leitura detida do prefácio pode indicar não só os detalhes dessas primeiras composições, como marcar um método seguido pelo autor ao longo de sua vida literária: a caracterização opositiva das personagens.

\section{Referências bibliográficas}

ASSIS, Joaquim Maria Machado de. Obra completa. COUTINHO, Afrânio (org.). Rio de Janeiro: Nova Aguilar, 1997. (V. I e III).

BAPTISTA, Abel Barros. A formação do nome: duas interrogações sobre Machado de Assis. Campinas: Editora Unicamp, 2003.

BARRETO FILHO, José. Machado de Assis. In: COUTINHO, Afrânio (org.). A literatura no Brasil. 2. ed. Rio de Janeiro: Editorial Sul Americana S.A, 1969.

CHALHOUB. Diálogos políticos em Machado de Assis. In: CHALHOUB, S.; PEREIRA, L. (org.). A história contada: capítulos de história social da literatura no Brasil. Rio de Janeiro: Nova Fronteira, 1998.

CALDWELL, Helen. O Otelo brasileiro de Machado de Assis. Trad. de Fábio Fonseca de Melo. São Paulo: Ateliê Editorial, 2002.

CASTELLO, José Aderaldo. Realidade e ilusão em Machado de Assis. São Paulo: Companhia Editora Nacional, 1969.

DIMAS, Antonio. Natureza 1 X Destino 0. Ressurreição. 6. d. São Paulo: Ática, 1983. GLEDSON, John. Machado de Assis: impostura e realismo. Trad. de Fernado Py. São Paulo: Companhias das Letras, 1991.

GUIMARÃES, Hélio de Seixas. Os leitores de Machado de Assis: o romance machadiano e o público de literatura no século 19. São Paulo: Nankin, 2004. 
MERQUIOR, José Guilherme. Machado de Assis e a prosa impressionista. De Anchieta a Euclides; breve história da literatura brasileira. Rio de Janeiro: José Olympio, 1977.

MOISÉS, Massaud. Machado de Assis. História da literatura brasileira. Realismo. São Paulo: Cultrix; Edusp, 1983.

MUIR, Edwin. A estrutura do romance. Trad. de Maria da Gloria Bordini. São Paulo: Globo, 1975.

SCHÜLER, Donaldo. A teoria do romance. São Paulo: Ática, 1989.

SCHWARZ, Roberto. Ao vencedor as batatas: forma literária e processo social nos inícios do romance brasileiro. São Paulo: Duas Cidades, 1977.

SCHWARZ, Roberto. A poesia envenenada de Dom Casmurro. Duas meninas. São Paulo: Companhia das Letras, 1997.

TEIXEIRA, Ivan. Apresentação de Machado de Assis. 2. ed. São Paulo: Martins Fontes, 1988.

VOLOBUEF, Karin. Fretas e arestas: a prosa de ficção do Romantismo na Alemanha e no Brasil. São Paulo: Editora da Unesp, 1999.

Title: The prefaces of the novels and the initial composition method of Machado de Assis

Abstract: This article argues the importance of the introductory texts for the understanding of the ficcional work of Machado de Assis, detaching the preface of his first novel, Ressurreição, of 1872. In it, the writer points its method of ficcional construction based on the characterization and opposition of the characters from some verses of Shakespeare.

Keywords: Preface. Novel. Composition. Character. Opposition.

Recebido em: 23/12/2012. Aceito em 17/06/2013. 